Глухівський національний педагогічний університет імені Олександра Довженка, ORCID ID 0000-0003-1474-3879

Антон Гребеник

Глухівський національний педагогічний університет імені Олександра Довженка,

ORCID ID 0000-0002-3051-5713

DOI 10.24139/2312-5993/2020.01/239-248

\title{
ДУАЛЬНА ОСВІТА ЯК ІННОВАЦІЙНА ФОРМА ПІДГОТОВКИ ФАХІВЦІВ У ЗАКЛАДАХ ВИЩОї ОСВІТИ
}

У статті представлено та охарактеризовано дуальну освіту як інноваційну форму підготовки фахівців у закладах освіти; зосереджено увагу на ролі практичної підготовки фрахівця як невід'ємної умови профресійного ставлення в період ринкової трансформації економіки; зроблено посилання на досвід Німеччини у впровадженні дуальної освіті, на нормативні документи цієї країни та нашої держави: окреслено коло осіб, які мають право на здобуття освіти за дуальною формою навчання, та перспективи їх працевлаштування. Акцентовано, що при цьому практична підготовка $\epsilon$ невід'ємною умовою професійного становлення, а дуальна форма здобуття освіти є актуальною та затребуваною часом.

Ключові слова: дуальна форма здобуття освіти, заклад освіти, професійна підготовка, професійна діяльність, професійна соціалізація, кадровий потенціал.

Постановка проблеми. «Сучасний етап державотворення в Україні характеризується недосконалістю механізмів взаємодії вищої освіти й ринку праці, ефективної підготовки майбутніх професіоналів і їх подальшого працевлаштування» (Кримчак, 2019). Сучасний ринок праці вимагає суттєвих змін освітньої галузі. Нині керівників бізнесу цікавить рівень готовності майбутніх фахівців до професійної діяльності. Випускники закладів освіти мають продемонструвати роботодавцеві не стільки теоретичні знання, скільки практичні вміння й навички. Освітній процес сучасного закладу слід зорієнтувати на формування особистості майбутнього фахівця, його готовності до вирішення нестандартних професійних завдань, підвищення рівня соціальної та професійної мобільності. При цьому практична підготовка $\epsilon$ невід'ємною умовою професійного становлення. У цьому контексті актуальною педагогічною проблемою є дуальна форма здобуття освіти.

Аналіз актуальних досліджень. Аналіз наукової літератури й нормативних документів свідчить про зростання в науково-освітньому просторі уваги науковців до питання дуальної форми здобуття освіти. Сучасні українські вчені досліджують різні аспекти: О. Бегма (підготовленість 
випускників закладів вищої освіти до професійної діяльності на виробництві), І. Бойчевська (роль системи дуальної освіти у професійній підготовці молоді), В. Вем'ян (дуальна форма професійної освіти як умова ефективного рішення завдань модернізації освіти), К. Яковенко (дуальна система навчання $\epsilon$ однією з ефективних моделей кооперації навчання й виробництва), Л. Кримчак (соціальне партнерство освіти та виробництва) та ін.

Метою статті $\epsilon$ обґрунтування необхідності й важливості впровадження до освітнього процесу дуальної форми навчання, приверненні уваги до проблем професійної підготовки в закладах освіти, визначенні поняття «дуальна форма здобуття освіти», узагальненні наявного досвіду з окресленого питання.

Методи дослідження. Для досягнення поставленої мети та вирішення завдань дослідження нами використано комплекс взаємопов'язаних теоретичних методів: аналіз, синтез, порівняння, зіставлення різних поглядів на проблему дослідження, узагальнення.

Виклад основного матеріалу. «У період ринкової трансформації економіки та масовізації вищої освіти відбулося знецінення традицій практичної підготовки здобувачів освіти, поширились імітація та фальсифікація практики, чимало організацій взагалі відмовилися працювати зі студентами, посилаючись на збереження комерційної таємниці або складні конкурентні обставини» (Закон України «Про освіту»). Серед проблем освітньої галузі, які покликана вирішити дуальна форма навчання, $є$ : недостатня відповідність професійної підготовленості випускника закладу освіти до потреб роботодавця, побоювання випускників працювати за фахом, недостатній досвід самостійної діяльності за обраною професією під час вибору першого робочого місця та ін.

«Проблему ускладнює те, що державні стандарти освіти, на які за визначенням повинні орієнтуватися 3ВО, розробляються неприпустимо повільно. Як результат, з цілої низки спеціальностей українські університети позбавлені сучасних якісно розроблених державних орієнтирів підготовки фахівців, які 6 утілювали в собі вимоги Закону «Про вищу освіту», відображали потреби ринку праці та суспільства загалом» (Ковтун, Сидоренко).

Проблемою сьогодення є невідповідність матеріальної бази закладів освіти сучасному виробництву, і вона вирішується по-різному. «Мало не повсюдними є ситуації, коли підприємство не може інтегрувати випускника вишу, бо на практиці його знання й навички «відірвані» від реальних потреб» (Бегма, 2018). Але слід відзначити, що за умови впровадження дуальної освіти чи їі елементів у освітні процеси закладів освіти зазначені проблеми не будуть перепонами в отриманні якісної освіти.

Державно-приватне партнерство закладів освіти з виробництвом і бізнес-структурами - це така система, яка об'єднає зусилля в напрямі забезпечення здобувачам її якості. 
Оскільки в нашій державі дуальна освіта робить лише перші кроки на шляху до системного партнерства виробничих підрозділів та 3ВО, в нагоді може стати вивчення досвіду інших країн.

Нами проаналізовані дослідження вітчизняних учених щодо впровадження дуальної форми навчання в освітні заклади Німеччини. Так, І. Бойчевська, вивчаючи досвід цієї країни, виокремлює чотири управлінські аспекти освітньої політики щодо виробничого навчання в межах дуальної системи освіти, а саме: державне регулювання (Закон про професійну освіту та нормативні акти), виробниче регулювання (укладання договорів, здійснення навчання на базі підприємства), соціальне партнерство (взаємодія представників роботодавців і найманих працівників), корпоративне регулювання (контроль за дотриманням правових і навчальних норм у процесі професійної підготовки).

«У педагогіці поняття «дуальна система» вперше було використане у ФРН у середині 1960 років для позначення нової форми організації професійного навчання, що пізніше поширилась і на інші німецькомовні країни Австрію, Швейцарію. Дуальна освіта визначається як така, що поєднує навчання в професійному училищі та на підприємстві» (Бойчевська, 2009).

Після закінчення неповної середньої школи чи отримання атестату про середню освіту 70 \% молоді Німеччини робить вибір на користь дуальної освіти (від лат. chalis- подвійний) та отримує одну з 350 ліцензованих у країні професій. Учні 1-2 дні на тиждень вивчають теоретичний курс безпосередньо в закладі освіти (профтехучилищі), а відповідно 3-4 дні на виробництві оволодівають навичками практичного навчання. Якщо випускник середньої школи не продовжує навчання в загальноосвітній гімназії, то він має обов'язково отримати професійну підготовку як основу для підвищення кваліфікації, отримання звання майстра чи започаткування власної справи. Підприємства долучаються до створення матеріальної бази та підготовки кадрів. При цьому несуть фінансові витрати, а відтак є зацікавленими як у змісті навчання, так і в його організації (Бойчевська, 2009); Марчук, 2007).

у Німеччині дуальна освіта $€$ засобом професійної соціалізації молоді, яка отримує найкращі можливості для отримання кваліфікації. I основним джерелом формування молодої генерації кваліфікованих німецьких робітників. Завдяки тісному зв'язку зі сферою праці вона забезпечує оптимальний старт трудового життя.

У справі розроблення тих чи інших аспектів стратегії та політики професійної освіти особливе значення має процес узгодження позицій і співпраця представників роботодавців і профспілок, державних і недержавних структур у межах спільної діяльності у Федеральному інституті професійної освіти.

«30/70» - такий принцип інноваційної форми навчання в Німеччині. 30 - теоретичний курс у закладі освіти, а 70 - безпосередньо професійна 
діяльність на виробництві. При цьому роботодавець «ростить» свого працівника, помічаючи більш успішних, пропонуючи робочі місця по завершенню навчання кращим. Протягом усього терміну навчання роботодавець формує повний психологічний портрет претендента на працевлаштування, тож тримісячний випробувальний термін не має в цій ситуації сенсу. Також зазначимо, що курсові та дипломні роботи за дуальної форми навчання - це реальні дослідження професійних завдань і вирішення існуючих проблем на виробництві чи в певній установі.

Тож німецька система дуальної освіти обстоює принципи обов'язкової наближеності як курсових, так і дипломних проєктів до реальних виробничих проблем, задач, запитів, викликів. Логічно передбачити, що віддаленість тих чи інших проєктів зводить нанівець зусилля студента, який вирішував «примарне» завдання.

Дуальна освіта як інноваційна форма підготовки фахівців у закладах вищої освіти України реалізується нині на основі низки нормативних документів: Законів України «Про освіту», «Про вищу освіту», «Про зайнятість населення», «Кодекс законів про працю України»; «Концепції підготовки фахівців за дуальною формою здобуття освіти», з урахуванням постанови Кабінету Міністрів України «Про затвердження Порядку укладання договору про стажування студентів вищих та учнів професійнотехнічних навчальних закладів на підприємствах, в установах та організаціях і Типової форми договору про стажування студентів вищих та учнів професійно-технічних навчальних закладів на підприємствах, в установах та організаціях» та ін.

Одним зі стратегічних напрямів модернізації вищої освіти є дуальні освітні програми. Вони розширюють шанси закладів освіти на успішне функціонування й гармонійний розвиток в умовах глобалізації ринку освітніх послуг.

Дуальна освіта сприяє більш глибокому й різнобічному професійному розвитку студентів, що підвищує їх конкурентоспроможність на ринку праці (Яковенко, 2016).

У Концепції підготовки фахівців за дуальною формою здобуття освіти «важливим $є$ створення умов для поєднання роботи з навчанням як у форматі здобуття освіти за вечірньою або заочною формою навчання, так і у форматі практичної підготовки здобувачів вищої освіти денної форми навчання та здобувачів професійної (професійно-технічної) освіти на робочих місцях» (Кримчак, 2019).

У наказі МОН «Щодо запровадження пілотного проєкту в закладах фахової передвищої та вищої освіти з підготовки фахівців за дуальною формою здобуття освіти» затверджено перелік закладів його реалізації. Однак, у цьому самому документі зазначається, що директорат вищої освіти й освіти дорослих щорічно за поданням керівників закладів 
здійснюватиме корегування цього списку учасників проєкту (Наказ МОН №1296 від 15.10.19p. «Щодо запровадження пілотного проекту закладах фахової передвищої та вищої освіти з підготовки фахівців за дуальною формою здобуття освіти»).

Під час презентації проєкту Міністерства закордонних справ Німеччини «Пілотний проєкт дуальної вищої освіти в Україні», яка відбулася під час семінару «Практичні кроки по впровадженню дуальної освіти в вищих навчальних закладах України» у Федерації роботодавців України було зазначено, що «вирішення проблемних питань у сфері вищої та технічної освіти $€$ нагальним питанням, оскільки рівень кваліфікацій, який отримують випускники закладів освіти, не відповідає потребам роботодавців». А під час проведення заходу зазначалося як роботодавцями, так і освітянами, що дуальна форма освіти забезпечить підготовку студентів до реальних вимог роботодавців, забезпечить високий рівень кваліфікації випускника, вирішить кадрові питання (Дуальна освіта - ключовий пріоритет українських роботодавців. Федерація роботодавців України).

Звичайно, забезпечення високого рівня кваліфікації випускників $\epsilon$ постійним завданням будь-якого рівня освіти. Проте дуальна освіта як одна з інноваційних форм підготовки фахівців покликана вирішити кадрові питання як виробництва, так і закладів освіти.

«Дуальна форма здобуття освіти передбачає навчання на робочому місці з виконанням посадових обов'язків відповідно до умов трудового договору» (Кримчак, 2019). Набуті в ЗВО знання студент поглиблює та закріплює на виробництві; він чітко бачить коло своїх посадових обов'язків та вимог, які висуває трудовий договір.

Дуальна система підготовки - «одна 3 найефективніших форм підготовки кадрів у світі, яка широко розповсюджена в промислово розвинених країнах і є основною системою підготовки кадрів» (Яковенко, 2016).

Упровадження дуальної форми освіти в Україні $\epsilon$ перспективним напрямом розвитку ЗВО, сфери вищої та технічної освіти. А вивчення досвіду європейських країн щодо її організації сприятиме налагодженню системи підготовки висококваліфікованих кадрів в Україні.

У Законі України «Про освіту» зазначено, що «основними формами здобуття освіти є: інституційна (очна (денна, вечірня), заочна, дистанційна, мережева); індивідуальна (екстернатна, сімейна (домашня), педагогічний патронаж, на робочому місці (на виробництві); дуальна» (Закон України «Про освіту»).

Дуальна форма здобуття освіти - це спосіб отримання освіти, який поєднує навчання осіб у закладах освіти з навчанням на робочих місцях на підприємствах, в установах, організаціях на основі договору з метою набуття певної кваліфікації. Вона омріяний формат сучасної молоді. Ще перебуваючи в стінах закладів здобувачі освіти мають оптимальну 
можливість отримати певну самостійність, мати грошову винагороду за свою працю, менш проблематично адаптуватися як до дорослого життя, так і до умов професійної діяльності.

На шляху до впровадження в закладах освіти цієї форми підготовки фахівців важливим $\epsilon$ досягнення балансу інтересів закладів освіти, роботодавців та здобувачів освіти.

Дуальну форму навчання мають право обирати здобувачі освіти, які навчаються за денною або іншими формами здобуття освіти й виявили особисте бажання та пройшли відбір у роботодавця. Зі здобувачем освіти укладається тристоронній договір: із закладом освіти та роботодавцем щодо навчання за дуальною формою здобуття освіти, і має кожен виконувати свої зобов'язання в межах договору. Така тісна співпраця виробничих структур і закладів освіти, як показує зарубіжний досвід, $є$ результативною та дає право говорити про певні переваги дуальної форми навчання. «Дуальна освіта має безліч переваг перед традиційною системою, що використовується на сьогоднішній день в Україні. Однак для того щоб реалізувати головні постулати дуального навчання, потрібно, щоб соціум був до цього готовий. Звертаючи увагу на величезний стрибок у розвитку української школи, можна незабаром очікувати змін у системі освіти університетів і коледжів. Дуальна система - один із найефективніших способів узгодити принципи вищої та професійної освіти в Україні» (Дуальна система освіти: про принципи і можливості реалізації в Україні, с. 1).

Дуальна освіта як інноваційна форма підготовки фахівців у закладах вищої освіти сприяє підвищенню рівня мотивації до навчання здобувачів освіти, систематичному перегляду освітніх програм з ініціативи та за участю роботодавців відповідно до модернізації виробництва, залученню працівників виробництва до освітньої діяльності, наближенню набутих випускником професійних компетентностей до вимог ринку праці, підвищенню рівня конкурентоздатності випускників закладів освіти на ринку праці через залучення роботодавців до організації освітнього процесу, зайнятості молоді, можливості навчання під час професійної діяльності, забезпеченню випускників робочими місцями, швидкій адаптації випускників на першому робочому місці тощо. При цьому здобувачі освіти, роботодавці та заклад освіти $€$ рівноправними партнерами організації освітнього процесу професійної підготовки майбутнього фахівця. Саме усвідомлення партнерами своєї рівноправності в цьому напрямі стане запорукою успішної співпраці всіх зацікавлених сторін.

Набуття практичних професійних компетентностей $\epsilon$ спільним завданням закладів освіти та роботодавців. Взаємопроникнення науки, виробництва, освіти та громадського сектору в середовищі дуальної форми підготовки фахівців забезпечать упровадження інноваційних змін, підвищення якості освітнього процесу. 
Навчання нового покоління має здійснюватися по-новому: нові підходи, методи, форми тощо. Імпульсивність сучасних здобувачів освіти не завжди поєднується з глибокою допитливістю. При цьому поверховість сприйняття знань не заважає прагненню, сильній мотивації застосувати отриману інформацію на практиці. I саме тому дуальна форма здобуття освіти $\epsilon$ актуальною та затребуваною часом. Обґрунтований баланс теорії та практики під час освітнього процесу забезпечує скорочення терміну адаптації до умов професійної діяльності, зменшує ризики щодо швидкої та частої зміни професії тощо.

Висновки та перспективи подальших наукових розвідок. Дуальна освіта $\epsilon$ інноваційною формою підготовки фахівців у закладах вищої освіти. Вона реалізується відповідно до низки нормативних документів і покликана забезпечити підготовку студентів до реальних вимог роботодавців і забезпечити високий рівень кваліфікації випускника.

Дуальні освітні програми - стратегічний напрям модернізації вищої освіти. Він розширює шанси закладів освіти на успішне функціонування й гармонійний розвиток у конкурентних умовах ринку освітніх послуг. Досвід європейських країн, зокрема Німеччини, передує реалізації дуальної форми навчання в Україні.

Перспективи подальших наукових досліджень полягають у доступному викладі головних постулатів дуального навчання, вивченні основних аспектів готовності соціуму до впровадження цієї форми навчання, розробка методів вивчення шляхів досягнення балансу інтересів закладів освіти, роботодавців та здобувачів освіти. Подальших наукових розвідок потребують методи, форми, технології дуальної форми здобуття вищої освіти в Україні.

\section{ЛІТЕРАТУРА}

Концепція підготовки фахівців за дуальною формою здобуття освіти. Режим доступу: https://zakon.rada.gov.ua/laws/show/660-2018-\%D1\%80/print (The concept of specialists' training in the dual form of education. Retrieved from: https://zakon.rada.gov.ua/laws/ show/660-2018-\%D1\%80/print).

Закон України «Про освіту». Режим доступу: https://zakon.rada.gov.ua/laws/show/214519\#n3 (Law of Ukraine "On Education". Retrieved from: https:// zakon.rada.gov.ua/laws/ show/2145-19\#3).

Бойчевська, І. (2009). Роль системи дуальної освіти у професійній підготовці молоді у Німеччині.

Режим доступу: https://library.udpu.edu.ua/library_files/poriv_ped_stydii/2009/2009_2_8.pdf (Boichevska, I. (2009). The role of the dual education system in vocational training for young people in Germany. Retrieved from: https://library.udpu.edu.ua/library_files/poriv_ped_stydii/2009/2009_2_8.pdf).

Марчук, Е. В. (2007). Современные тенденции развития начального профессионального образования в Германии. Вестник ТГпу, 7 (70), 144-145. (Marchuk, E. V. (2007). Current trends in the development of primary vocational education in Germany. Newsletter TSGU, 7 (70), 144-145). 
Herbert Baumann (1989). Wirtschaftslehre fur berufsbildende Schulen in Rheinland- Pfalz. Koln-M unchen: Stamm-Verlag, 250.

Наказ МОН № 1296 від 15.10.19 р. «Щодо запровадження пілотного проекту закладах фахової передвищої та вищої освіти з підготовки фахівців за дуальною формою здобутmя освіти». Режим доступу: https://mon.gov.ua/ua/npa/shodozaprovadzhennya-pilotnogo-proektu-u-zakladah-fahovoyi-peredvishoyi-ta-vishoyi-osvitiz-pidgotovki-fahivciv-za-dualnoyu-formoyu-zdobuttya-osviti (M inister of education and science Order No. 1296 of October 15, 19 "On the introduction of the pilot project of institutions of professional higher and higher education for the training of specialists in the dual form of education". Retrieved from: https://mon.gov.ua/ua/npa/shodozaprovadzhennya-pilotnogo-proektu-u-zakladah-fahovoyi-peredvishoyi-ta-vishoyi-osvitiz-pidgotovki-fahivciv-za-dualnoyu-formoyu-zdobuttya-osviti)

Дуальна система освіти: про принципи і можливості реалізації в Україні. Режим доступу: https://buki.com.ua/news/dualna-systema-osvity-pro-pryntsypy-imozhlyvosti-realizatsiyi-v-ukrayini/ (Dual system of education: about principles and possibilities of realization in Ukraine. Retrieved from: https://buki.com.ua/news/dualna-systema-osvity-pro-pryntsypy-i-mozhlyvostirealizatsiyi-v-ukrayini/).

Ковтун, О., Сидоренко, С. Незалежне оцінювання якості освітніх послуг здобувачами вищої освіти: досвід та перспективи. Режим доступу: file://C:/Users/admin/Downloads/12910-33552-1-SM .PDF (Kovtun, O., Sidorenko, S. Independent assessment of the quality of educational services by higher education recipients: experience and perspectives. Retrieved from: file:///C:/Users/admin/Downloads/12910-33552-1-SM .PDF).

Яковенко, К. В. (2016). Реалізація дуальної системи освіти в підготовці майбутніх фахівців 3 інформачійних технологій. Режим доступу: http://repository.kpi.kharkov.ua/bitstream/KhPI

Press/25362/1/Elita_2016_45_1_Yakovenko_Realizatsiia.pdf (Yakovenko, K. V. (2016). Implementation of a dual education system in the training of future IT professionals. Retrieved from: http://repository.kpi.kharkov.ua/bitstream/KhPI Press/25362/1/Elita_2016_45_1_Yakovenko_Realizatsiia.pdf).

Кримчак, Л. Ю. (2019). Система дуальної освіти як умова якісної підготовки конкурентоспроможних профресіоналів до ринку праці в Україні. Режим доступуж http://www.innovpedagogy.od.ua/archives/2019/11/part_2/20.pdf (Krymchak, L. Yu. (2019). Dual education system as a condition for qualitative preparation of competitive professionals in the labor market in Ukraine. Retrieved from: http:// www.innovpedagogy.od.ua/archives/2019/11/part_2/20.pdf).

Бегма, О. (2018). На виробництво - вже підготовленим. Сільські вісті, 15. Режим доступу: $\quad$ http://www.silskivisti.kiev.ua/19562/index.php?n=38199 (Begma, 0. (2018). For production - already prepared. Village news, 15. Retrieved from: http://www.silskivisti.kiev.ua/19562/index.php?n=38199).

Вем'ян, В. Г. (2015). Дуальна форма професійної освіти як умова ефективного рішення завдань модернізації освіти. Психологія: реальність і перспективи, 5, 29-34. (Vemyan, V. G. (2015). Dual form of vocational education as a condition for effective solution of the problems of education modernization. Psychology: Reality and $\begin{array}{llll}\text { Perspectives, } & 5, \quad 29-34 . & \text { Retrieved }\end{array}$ http:// openarchive.nure.ua/bitstream/document/ 7811/1/\%d0\%94\%d0\%a3\%d0\%90\%d0 \%9b\%d0\%ac\%d0\%9d\%d0\%90\%20\%d0\%a4\%d0\%9e\%d0\%a0\%d0\%9c\%d0\%90\%20\%d0\%9 f\%d0\%a0\%d0\%9e\%d0\%a4\%d0\%95\%d0\%a1\%d0\%86\%d0\%99\%d0\%9d\%d0\%9e\%d0\%87\% 
20\%d0\%9e\%d0\%a1\%d0\%92\%d0\%86\%d0\%a2\%d0\%98\%20\%d0\%af\%d0\%9a\%20\%d0\%a3 \%d0\%9c\%d0\%9e\%d0\%92\%d0\%90\%20\%d0\%95\%d0\%a4\%d0\%95\%d0\%9a\%d0\%a2\%d0\%9 8\%d0\%92\%d0\%9d\%d0\%9e\%d0\%93\%d0\%9e\%20\%d0\%a0\%d0\%86\%d0\%a8\%d0\%95\%d0 \%9d\%d0\%9d\%d0\%af\%20\%d0\%97\%d0\%90\%d0\%92\%d0\%94\%d0\%90\%d0\%9d\%d0\%ac\%2 0\%d0\%9c\%d0\%9e\%d0\%94\%d0\%95\%d0\%a0\%d0\%9d\%d0\%86\%d0\%97\%d0\%90\%d0\%a6\% d0\%86\%d0\%87\%20\%d0\%9e\%d0\%a1\%d0\%92\%d0\%86\%d0\%a2\%d0\%98.pdf).

Дуальна освіта - ключовий пріоритет українських роботодавців. Федерація роботодавців України. Режим доступу: http://fru.ua/ua/mediacenter/archive/dualna-osvita-kliuchovyi-priorytet-ukrainskykh-robotodavtsiv (Dual education is a key priority for Ukrainian employers. Federation of Employers of Ukraine. Retrieved from: http://fru.ua/ua/media-center/archive/dualna-osvitakliuchovyi-priorytet-ukrainskykh-robotodavtsiv).

\section{PEЗЮME}

Курок Вера, Гребеник Антон. Дуальное образование как инновационная форма подготовки специалистов в учреждениях высшего образования.

В статье представлено и охарактеризовано дуальное образование как инновационная форма подготовки специалистов в учебных заведениях; сосредоточено внимание на роли практической подготовки специалиста как неотъемлемого условия профессионального становления в период рыночной трансрормации экономики; сделано акцент на опыте Германии по внедрению дуального образования, на нормативные документы этой страны и нашего государства; определен круг лиц, имеющих право на получение образования за дуальной формой обучения и перспективы их трудоустройства. Акцентировано, что при этом практическая подготовка является неотъемлемым условием профессионального становления, а дуальная форма получения образования является актуальной и востребованной временем.

Ключевые слова: дуальная форма получения образования, учебное заведение, профессиональная подготовка, профессиональная деятельность, профрессиональная социализация, кадровый потенциал.

\section{SUMMARY}

Kurok Vera, Grebenik Anton. Dual education as an innovative form of specialist's training in higher education institutions.

The article presents and describes dual education as an innovative form of specialist's training in education institutions; focuses on the role of the specialist's practical training as an indispensable condition of professional attitude during the period of market transformation of the economy; reference is made to the experience of Germany in the introduction of dual education, to the normative documents of this country and our state: the persons' circle entitled to receive education in dual education and employment prospects are outlined. It is emphasized that practical training is an indispensable condition for professional development, and the dual form of education is relevant and time consuming. Dual education programs are a strategic direction for the modernization of higher education. It enhances the chances of education institutions to operate and harmonize successfully in the competitive market of educational services.

The experience of European countries, including Germany, precedes implementation of dual education in Ukraine. In the development of various aspects of vocational education strategy and policy, the process of positions reconciling and representatives of employers and trade unions cooperation, state and non-state structures in the framework of joint activities 
on dual training is of particular importance. Introduction of dual education in Ukraine is a promising area for the development of higher educational establishments, higher education and technical education. And studying the experience of European countries regarding its organization will help to establish a system of training highly qualified personnel in Ukraine.

The dual form of education is a way of obtaining education that combines education of individuals in education institutions with on-the-job training at enterprises, institutions, organizations on the basis of a contract in order to acquire a certain qualification. It is the dreamy format of modern youth. Even within the walls of the education institutions, the educators have the optimum opportunity to gain some independence, to have a monetary remuneration for their work, and to adapt to adult life and professional conditions less problematic.

Key words dual form of education, educational establishment, vocational training, professional activity, professional socialization, human resources potential.

Удк 378.1:355.232.2

Роман Невзоров

Харківський національний університет Повітряних Сил імені Івана Кожедуба

ORCID ID 0000-0003-1496-2465

DOI 10.24139/2312-5993/2020.01/248-256

\section{НАЗЕМНЕ НАВЧАННЯ БОЙОВИМ ПОЛЬОТАМ ЯК УМОВА ЯКІСНОЇ ФАХОВОЇ ПІДГОТОВКИ МАЙБУТНІХ ЛЬОТЧИКІВ ТАКТИЧНОЇ АВІАЦІї}

Автором досліджено сучасні погляди на проблему наземного навчання бойовим польотам майбутніх льотчиків тактичної авіачії. Визначено завдання, психолого-педагогічні закономірності наземного навчання бойовим польотам та основні бойові якості майбутнього льотчика тактичної авіачії. Наземне навчання бойовим польотам схарактеризовано як самостійний напрям військової педагогіки. Обгрунтовано педагогічну систему «наземної бойової підготовки майбутніх льотчиків тактичної авіації».

Ключові слова: майбутній льотчик тактичної авіачії, навчання бойовим польотам, психолого-педагогічні закономірності, педагогічна система, прийоми навчання, зміст навчання.

Постановка проблеми. Одним 3 основних завдань освітнього процесу льотного закладу вищої військової освіти (ЛЗВВО) є формування в майбутніх льотчиків знань, умінь, навичок виконання бойових завдань. Зростання обсягів науково-технічної інформації, інтенсивне впровадження в бойове застосування авіації досягнень науки й техніки, розвиток тактичних прийомів і способів бойового застосування підрозділів авіації обумовили необхідність глибокого засвоєння великого обсягу знань із тактики авіації, набуття навичок із підготовки й виконання бойових польотів. Таким чином, постійний розвиток прийомів і способів збройної боротьби вимагає набуття майбутніми льотчиками тактичної авіації навичок самовдосконалення, що, у свою чергу, обумовлює необхідність адекватних змін у сфері навчання виконанню бойових польотів. 